\title{
Surge modelling in the eastern Irish Sea: present and future storm impact Jenny M. Brown ${ }^{1 *}$, Alejandro J. Souza ${ }^{1}$, Judith Wolf ${ }^{1}$
}

\section{Proudman Oceanographic Laboratory, 6 Brownlow Street, Liverpool L3 5DA, UK} phone: +44 (0)151 795 4971, fax: +44 (0)151 795 4801, email: jebro@pol.ac.uk

Keywords: Surge, Storm, Climate change, Irish Sea

\begin{abstract}
It is believed that in the future the intensity and frequency of extreme coastal flooding events may increase as a result of climate change. The NERC-FREE project (CoFEE) and EU FP7 project (MICORE) are investigating the flood risks in the eastern Irish Sea, an area that includes most of England's coastal types. Using a previously modelled and validated historical extreme surge event, in November 1977, we now investigate the changes in peak surge as a result of possible future climate conditions.
\end{abstract}

In order to simulate the surge, we have set up a one-way nested approach, using the POLCOMS 3D baroclinic model, from a domain covering the whole NW European continental shelf, through to a $1.85 \mathrm{~km}$ Irish Sea model, both areas are forced by tides, atmospheric pressure and winds. We use this modelling system to investigate the impact of enhanced wind velocities and increased sea levels on the peak surge elevation and residual current pattern. The results show that sea level rise has greater potential to increase surge levels than increased wind speeds.

\section{Introduction}

Future extreme coastal flooding events are expected to increase (in intensity and frequency) as a result of climate change. The NERC-FREE Coastal Flooding by Extreme Events (CoFEE) project and EU FP7 Morphological Impacts and COastal Risks induced by Extreme storm events (MICORE) project are investigating past, present and future storm events in Liverpool Bay and especially along the Sefton coastline (see Fig.1), where the mobile dunes exposed to the prevailing SW winds and depressions moving across the UK from west to east are at risk of enhanced erosion. The present-day surge conditions due to extreme events are being investigated using wave and surge modelling over an 11 year period (1996-2007). This paper uses a hindcast simulation of the November 1977 surge event, which caused significant flooding on the Sefton coast. We then study the sensitivity of the system by considering changes in the peak surge elevation resulting from this storm under future climate conditions. The future scenarios include increasing the mean sea level (by $0.7 \mathrm{~m}$ and $1.4 \mathrm{~m}$ ) and the wind strength (by $5 \%$ and $10 \%$ ) to look at the new surge levels that could arise in the future. The resulting surges are investigated at ports in the eastern Irish Sea. We present results for Hilbre, Heysham and Douglas (located in Fig. 3). Hilbre and Heysham represent shallow locations either side of the Sefton coastline, and thus give insight to the surge conditions that may occur along this stretch of coast. The Liverpool tide gauge had timing errors in its data, which is why we have concentrated on the results at Hilbre and not Liverpool. The surge results at Douglas have also been presented to show how the surge behaves at a deep location within the Liverpool Bay study area. To allow investigation of the full picture results are presented for both elevation and velocity.

The tide-surge modelling has been improved by implementing the Charnock (1955) method in place of Smith and Banke (1975) to calculate the wind surface stress, following Brown and Wolf (2009). Wu (1982) has shown that using a constant Charnock parameter captures most of the variation in surface roughness without the need for including wave effects over a range of winds speeds $(0-55 \mathrm{~m} / \mathrm{s})$, and thus sea states. Brown and Wolf (2009) have shown that within the eastern Irish Sea, where the waves are locally generated and shoaling a constant spatially-uniform Charnock parameter of 0.0185 is adequate for hindcasting surge events. This method therefore allows computations to be made without the need for a coupled wave-current model, thus limiting computational costs.

We use the Proudman Oceanographic Laboratory Coastal Ocean Modelling System (POLCOMS), as described in section 3, as a tide and surge modelling system in a one way nested framework from $\sim 12 \mathrm{~km}$ to $1.85 \mathrm{~km}$. A synoptic description of the storm event in November 1977 is given in section 2 and the performance of the modelling system and results are presented in section 4. Changes in sea level and wind forcing have been imposed, in section 5, to investigate future scenarios and provide insight into how the impact of such a severe storm combined with high spring tides might be increased in the future. The research concentrates mainly on surge elevation, but the residual surge current patterns are also briefly investigated. We discuss the results in section 6 followed by the conclusions in section 7 . 


\section{The November 1977 surge}

We revisit the surge of November 1977, a storm event which caused damage on the Sefton coast in NW England. This period has previously been thoroughly studied e.g. Jones and Davies (1998). The surge occurred on the $11^{\text {th }}-12^{\text {th }}$ November and was the result of an atmospheric depression crossing the region from west to east to the north of Scotland before moving on to northern Norway. This generated $16 \mathrm{~m} / \mathrm{s}$ south-westerly winds in the eastern Irish Sea, which increased to $22 \mathrm{~m} / \mathrm{s}$ and veered round to the west (Fig. 1) (Jones and Davies, 1998). The surge reached 1.5m at Liverpool (Fig. 2), while wave heights were of the order $3.5 \mathrm{~m}$ with $6 \mathrm{~s}$ periods. The external surge was generated by winds blowing over the south-west Irish Sea (Fig. 1a) and the local surge was generated by winds blowing over the eastern Irish Sea (Fig. 1b). This severe storm coincided with high water spring tide (Fig. 2) leading to severe flooding as water overtopped coastal defences throughout Merseyside, Lancashire and Cumbria. We assume that the worst flooding will occur due to any amount of positive surge at high water elevation, especially during spring tides. This event is used to investigate how the surge component is modified under future scenarios.
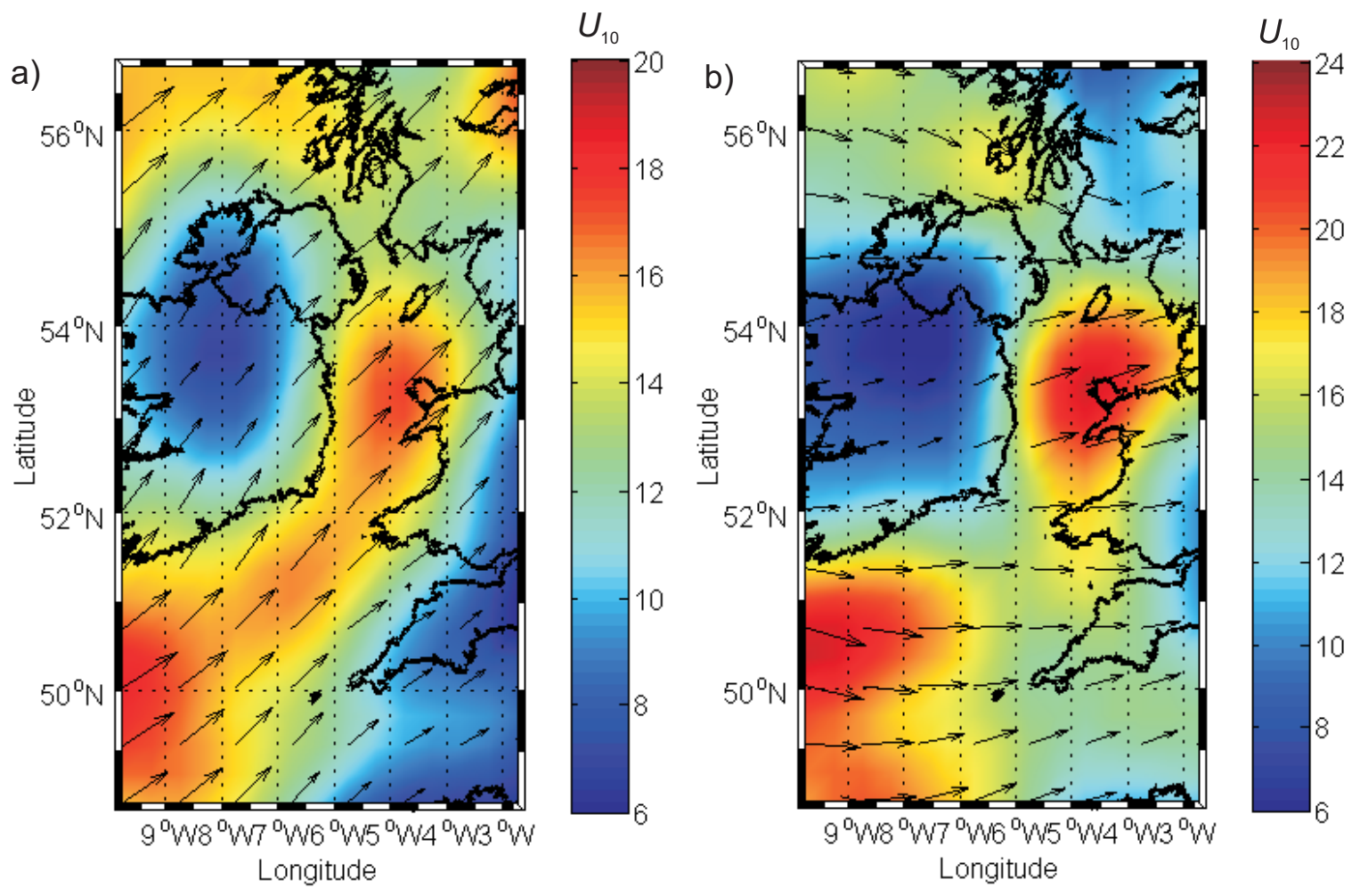

Fig. 1 The $10 \mathrm{~m}$ wind velocity $(\mathrm{m} / \mathrm{s})$ at a) 12:00 $11^{\text {th }}$ November 1977 and b) 00:00 $12^{\text {th }}$ November 1977 


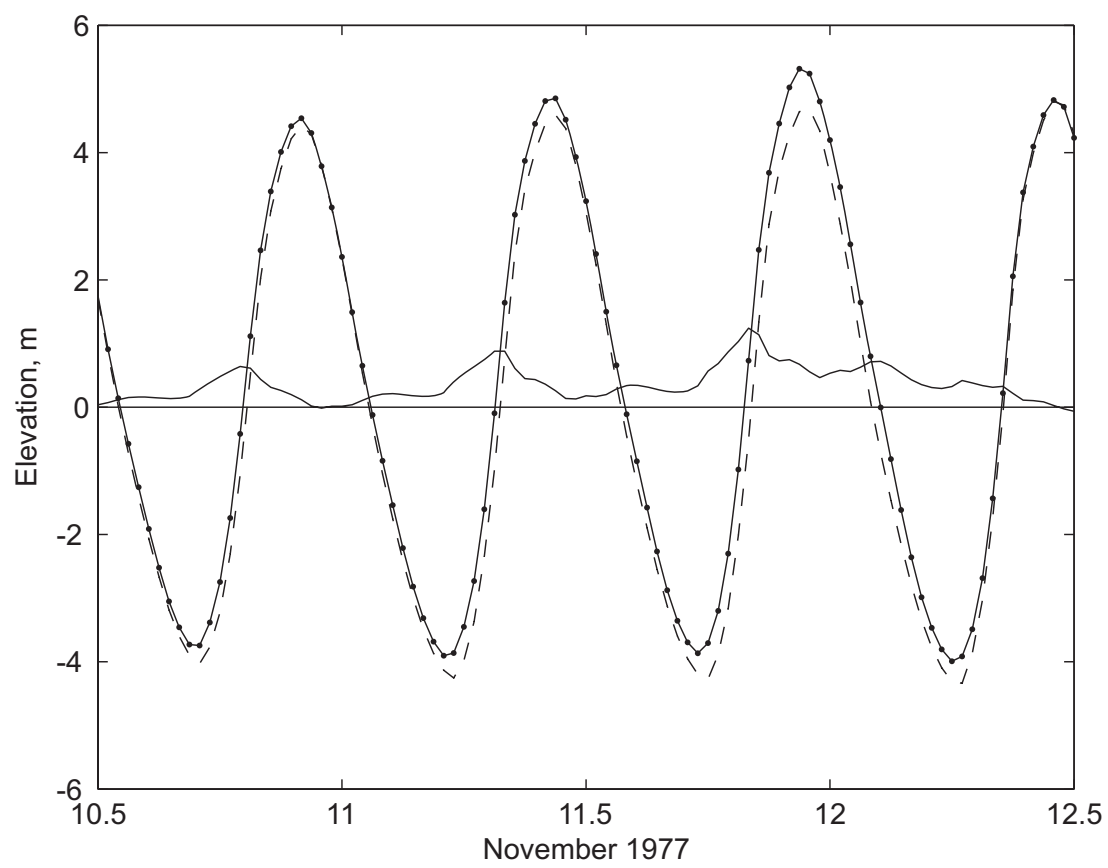

Fig. 2 The total (surge + tide) elevation $(-\bullet-)$, tidal elevation $(--)$ and surge elevation $(-)$ at Hilbre during the November 1977 event. The time resolution is the day in November, e.g. $10=00: 0010^{\text {th }}$ November and $10.5=12: 0010^{\text {th }}$ November

\section{Methods}

In order to accurately simulate the external surge-tide effects generated outside of the Irish Sea a one-way nested approach from a $1 / 9^{\circ}$ latitude by $1 / 6^{\circ}$ longitude $(\sim 12 \mathrm{~km})$ model of the whole NW European continental shelf, over which surges impacting the UK are generated, to the $1.8 \mathrm{~km}$ Irish Sea model has been applied. For the 1977 surge event the POLCOMS (Holt and James, 2001) Atlantic margin model (Fig. 3) was used to provide the boundary forcing. In the Irish Sea the standard Smith and Banke surface drag formulation for wind stress (1975), hereafter referred to as S\&B, has been replaced by the Charnock (1955) method to better simulate the surge event following Brown and Wolf (2009). The surge is defined as the difference in the total simulated water level and the modelled tide, i.e. the residual water level due to meteorological forcing. Here, the modelled tide was simulated using the 15 tidal constituents $\left(\mathrm{Q}_{1}, \mathrm{O}_{1}, \mathrm{P}_{1}, \mathrm{~S}_{1}\right.$, $\mathrm{K}_{1}, 2 \mathrm{~N}_{2}, \mu_{2}, \mathrm{~N}_{2}, v_{2}, \mathrm{M}_{2}, \mathrm{~L}_{2}, \mathrm{~T}_{2}, \mathrm{~S}_{2}, \mathrm{~K}_{2}$ and $\mathrm{M}_{4}$ ) available in POLCOMS. A minimum water depth of $5 \mathrm{~m}$ was applied, to avoid treating wetting and drying conditions. Brown and Wolf (2009) discuss using the predicted tide combined with the surge simulation to assess the flood risk using the total water level and the 'skew surge' to remove inaccuracy in the modelled tide. The 'skew surge' is defined as the difference between the predicted high tide and the actual high water level due to the tide and surge. 


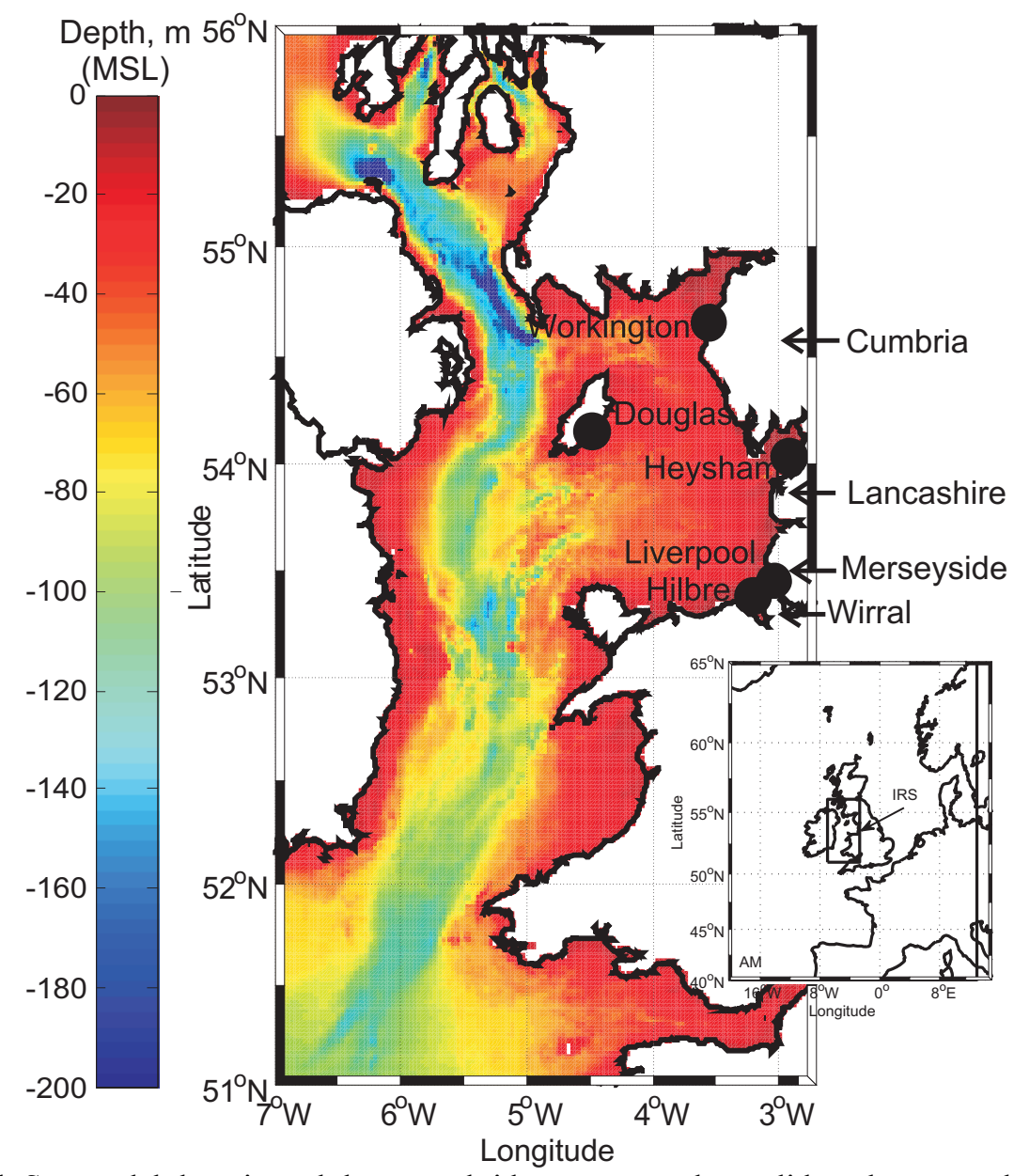

Fig. 3 The Irish Sea model domain and the coastal tide gauges used to validate the surge elevation predicted by the modelling system, during November $1977(+)$. The nested model domains for the Atlantic Margin model (AM) and the Irish Sea model (IRS) are shown in the bottom right corner

The coarse grid models for POLCOMS were driven by $1^{\circ}$ resolution ECMWF (ERA-40) atmospheric pressure and wind data provided every 6 hours. For the medium resolution Irish Sea model high resolution (both spatially, $1 / 2^{\circ}$ by $1 / 3^{\circ}$, and temporarily, 3 hourly) wind and pressure data (Jones \& Davies, 1998) were used to drive the model. The improved resolution of these data allows a more accurate simulation of the surge conditions in 1977. Surge elevation data obtained at five coastal tide gauges (Fig. 3) in the eastern Irish Sea during this event have been used to validate the model.

\subsection{Surface roughness}

To accurately predict surge conditions in the eastern Irish Sea different methods to predict the surface wind stress have been applied. Wind stress, $\tau$, is dependent on the air density, $\rho_{a}$, and friction velocity, $u_{*}$, which is related to the wind speed at $10 \mathrm{~m}, U_{10}$, where $C_{D}=$ a drag coefficient (Janssen, 2004):

$\tau=\rho_{a} u_{*}{ }^{2}=\rho_{a} C_{D} U_{10}{ }^{2}$

Charnock's (1955) method parameterises the roughness length, $z_{0}$, on dimensional grounds and has been found to be applicable from light to extreme (hurricane) wind conditions up to $60 \mathrm{~m} / \mathrm{s}(\mathrm{Wu}, 1982)$. By assuming momentum transfer from air to ocean is mainly through short surface gravity waves, then the roughness length is scaled by the acceleration of gravity, $g$, and $u_{*}$ :

$$
z_{0}=\frac{\alpha u_{*}^{2}}{g}
$$

The Charnock parameter, $\alpha$, is often treated as constant in models with values between 0.0112 and 0.035 (Wu, 1980). Although $\alpha=0.0185$ seems to provide accurate representation of the surface stress for all sea states (Wu, 1982), a larger constant value (0.0275) has also been found to be appropriate for surge modelling and is applied in the UK operational surge model (Williams and Flather, 2000). To model the surface drag to accurately predict the surge events both the methods of Smith and Banke (1975) (S\&B) and Charnock (1955) were previously investigated. Three constant Charnock parameters have been used. The first $(\alpha=0.0275)$ 
was found to give good surge prediction in the operational surge model over the whole UK shelf (Williams and Flather, 2000). The second $(\alpha=0.0144)$ was that used by Janssen (1989) to model the impacts of waves on the surface roughness. The third $(\alpha=0.0185)$ was found by $\mathrm{Wu}(1982)$ to give good surface stress prediction for all sea states (wind conditions). Brown and Wolf (2009) found the optimum constant and spatially uniform value for the eastern Irish Sea to be 0.0185 although this might be dependent on model resolution. Local modulation by wave age effects may provide some further improvement but this is not very significant in the eastern Irish Sea. We therefore use this Charnock constant to simulate the future scenario surge conditions investigated here.

\section{Results}

4.1 Hindcast surge elevation

In the following results, observed data at Heysham and Hilbre stop just after peak surge due to the tide gauges being damaged during the following tidal high water combined with the weakening but still significant surge levels.

Comparison of the surge elevation at coastal tide gauges across in the eastern Irish Sea (located in Fig. 3) has shown that there is significant tidal modulation in the surge (Fig. 2). The times of high water compared to the peaks in surge are shown in Figs. 2 and 4, where it may be seen that the peak surge residual occurs on the rising tide (i.e. approximately 3 hours before $\mathrm{HW}$ ). The large $(10 \mathrm{~m})$ tidal range in the eastern Irish Sea has significant effect on the depth-averaged surge generated by the wind stress in shallow coastal locations. The locally generated peaks in surge occur at low water levels when the water depths are shallowest, but tidesurge interaction due to tide and surge propagation means the peak surge occurs on rising tide (Horsburgh and Wilson (2007); Wolf, 1981). The data (Fig. 4) also shows that the surge is much greater ( 1m) along the Sefton coast (Heysham and Hilbre) compared with that occurring on the Isle of Man (Douglas). The higher constant value $(\alpha=0.0275)$ was found to be more accurate at capturing the peak surge at the deep tide gauge locations compared to the lower value ( $\alpha=0.0144$ ), and visa versa for the shallow tide gauge locations (Fig. 4). On average across the eastern Irish Sea the intermediate constant $(\alpha=0.0185)$ was found to most accurately model the peaks in tide-surge conditions (Fig. 4). Fig. 5 shows how the surge predicted using a Charnock method with $\alpha=0.0144$, is very similar to that predicted by S\&B. For this model resolution S\&B slightly under predicts the surge peaks, but still gives a reasonable prediction, unlike the predictions when using a coarse resolution model (Williams and Flather, 2000). Figures 4 and 5 show that a Charnock method with constant value of 0.0185 is the most appropriate method over time to simulate the surface roughness in a tide-surge model of the eastern Irish Sea, instead of the S\&B methods. 

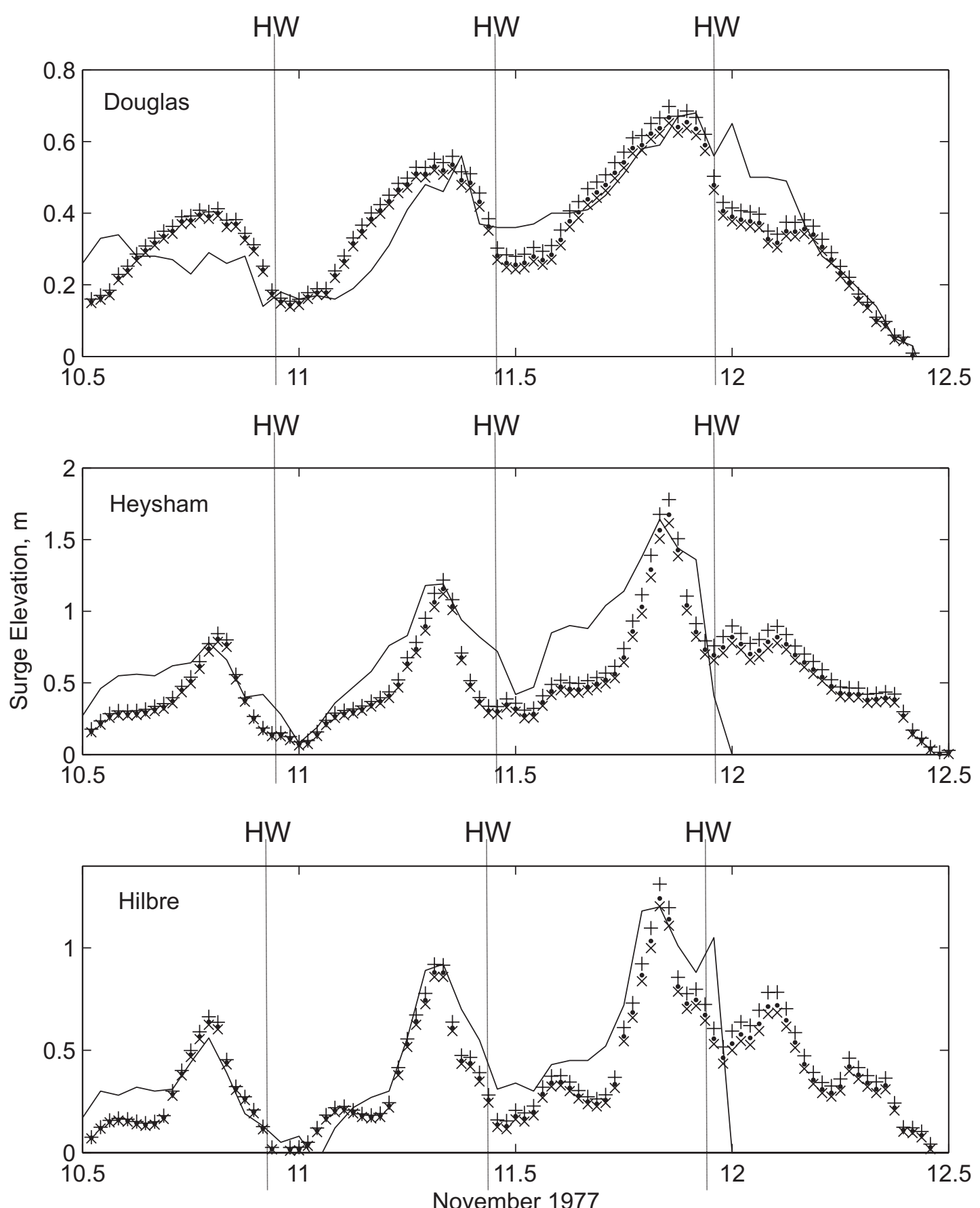

Fig. 4 Surge prediction using Charnock parameters of $0.0275(+), 0.0185(\bullet)$ and $0.0144(\times)$, using POLCOMS with a minimum depth of $5 \mathrm{~m}$, compared to tide gauge data $(-)$. Douglas represents a deep location, while Heysham and Hilbre represent shallow locations along the Sefton coast. The times of high water (HW vertical lines) are after the peaks in surge, which occur on the rising tide. The time resolution is the day in November, e.g. $10=00: 0010^{\text {th }}$ November and 10.5 $=12: 0010^{\text {th }}$ November 

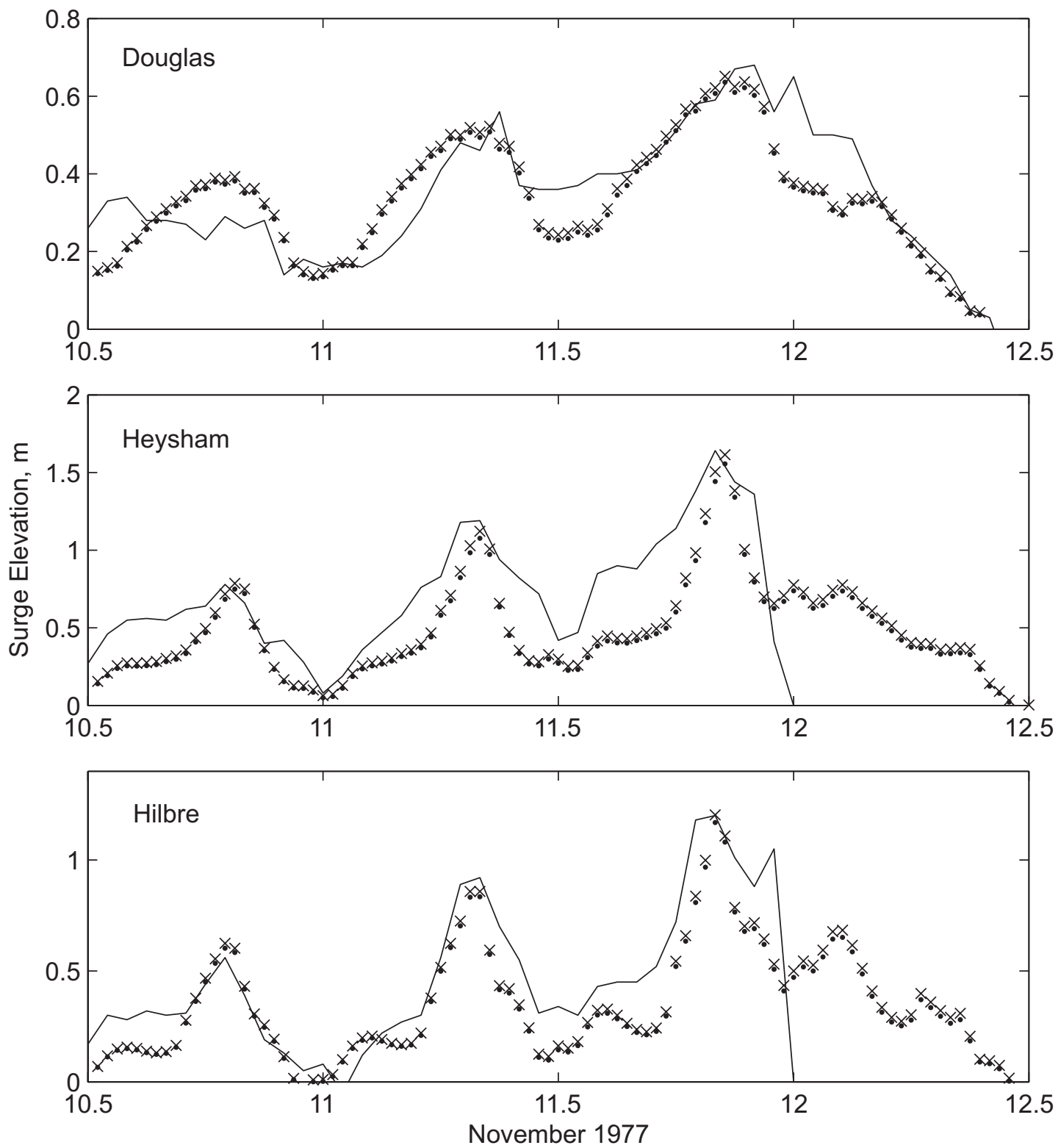

Fig. 5 Surge prediction using S\&B $(\bullet)$ and a Charnock parameter of $0.0144(\times)$, using POLCOMS with a minimum depth of $5 \mathrm{~m}$, compared to tide gauge data (-).Douglas represents a deep location, while Heysham and Hilbre represent shallow locations along the Sefton coast. The time resolution is the day in November, e.g. $10=00: 0010^{\text {th }}$ November and 10.5 $=12: 0010^{\text {th }}$ November

4.2 Simulated flow patterns

Although it is the water elevation that controls the extent of coastal flooding, future changes in the magnitude and extent of the current field in relation to the coast will modify natural defences and the beach profile along a coastline. In particular, the Sefton coastline has a vast extent of sand dunes and salt marsh providing a significant amount of protection at present. We therefore investigate the possible future changes in depthaverage current at the coastal tide gauge locations.

In the eastern Irish Sea the tide is asymmetric. The depth-averaged flow vectors are shown every 2 hours for Douglas, Heysham and Hilbre in Fig. 6. At Douglas, the deepest location, the tide is rectilinear with the flood tide directed in a (positive) northeast direction and ebb tide in a (negative) southwest direction. This rectilinear velocity pattern is a result of the coastline configuration in relation to the tide in the eastern Irish Sea. Interestingly although the flood tide is of shorter duration the peak ebb tide is a few $\mathrm{cm} / \mathrm{s}$ faster. At Heysham, a shallow location away from the influence of an estuary mouth, the tide is nearly rectilinear with the flood tide and ebb tide in the same direction as Douglas. Here, the flood tide is faster than the ebb as in typical flood tide asymmetry (short, fast flood and long slow ebb), but both are of similar strength to the currents at Douglas. At Hilbre, a shallow location in the mouth of the Dee Estuary, the tide is less rectilinear and floods towards the south (negative) and ebbs towards the north (positive). In this location the typical 
(for shallow water) flood tide asymmetry occurs, comprising of a significantly faster, shorter flood tide compared with the ebb. The flood tide at Hilbre is slightly weaker than that at Douglas and Heysham, while the ebb is much faster.
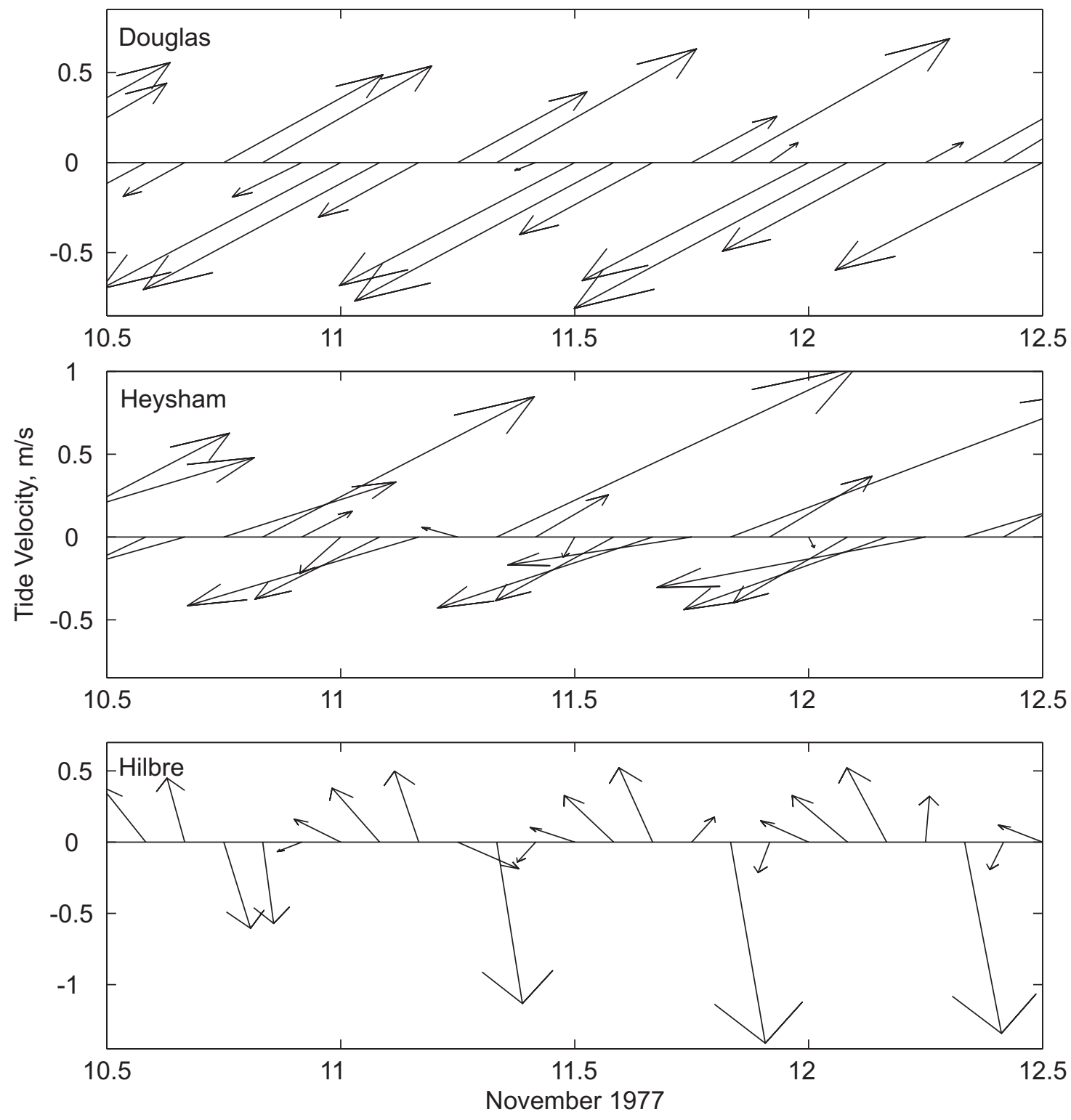

Fig. 6 Tide only depth - averaged current vectors every 2 hours at Douglas, Heysham and Hilbre, located in Fig. 3, during the period $10^{\text {th }}$ November $(12: 00)$ to $12^{\text {th }}$ November $(12: 00) 1977$. The time resolution is the day in November, e.g. $10=00: 0010^{\text {th }}$ November and 10.5 $=12: 0010^{\text {th }}$ November

\section{Future scenarios}

We used the November 1977 storm as our base storm to simulate future scenarios using combinations of (i) increased winds (by $5 \%$ and $10 \%$ ) and (ii) increased sea level (by $0.7 \mathrm{~m}$ and $1.4 \mathrm{~m}$ ). To simulate the effects of increased sea level the mean tidal level in the model was raised. Any non-linear effects due to tide-surge interaction in the deepened water are therefore captured. Since the surge is defined as the additional water on top of the tidal level we remove the present day tidal level from the future total water levels to compare the surge directly with present day tidal conditions. The rise in sea level at Liverpool is currently $1.4 \mathrm{~mm} /$ year (Woodworth et al, 1999); if rates remain constant these increased sea levels are unlikely to be achieved in the next 100 years. It is thought sea level rise will be of the order of meters over the next 15 to 100 years due to thermal expansion alone (ICPP, 2007), we therefore investigate multiples of $1.4 \mathrm{~mm} / \mathrm{year}$ to represent a sea level rise of this magnitude. These future scenarios have been simulated to give insight into what might occur in the future. The external surge important to the eastern Irish Sea is generated in the Celtic Sea and also enters from NW Approaches through the North Channel (Jones and Davies, 1998). These regions are included within the Irish Sea model used here; we have therefore not modified the boundary conditions to 
this model but allowed the external surge to the eastern Irish Sea to be changed as a result of increased wind forcing and sea level rise across the Irish Sea model domain.

\subsection{Future surge elevations}

We focus on three tide gauge locations, namely Douglas, Hilbre and Heysham. These three locations show the main changes in the surge along the Sefton coast and also at a deep and shallow coastal position. The percentage change in the peak surge elevation for Douglas $(0.668 \mathrm{~m}$ peak surge), Heysham $(1.673 \mathrm{~m}$ peak surge) and Hilbre (1.242m peak surge) are given in Table 1 and 2 respectively. Under all future scenario conditions the peaks in surge increase. The increase is much greater at the shallow locations compared to the deeper location. For the changes in sea level and wind speed we have de-tided the total water elevation to obtain the surge using the present day tide (sea levels). This allows us to see the total increase in surge elevation as a result of changes in the tide, surge and tide-surge interaction. The changes in sea level have more impact than the change in wind speed on the enhancement of the peak surge (Tables $1-3$ ). As expected the combined effect of increasing the wind speed and sea level led to the worst increase in peak surge. For shallow coastal locations such as Hilbre only a small increase in sea level $(+0.7 \mathrm{~m})$ causes a significant (15\%) enhancement in the peak surge. Along the Sefton coast stronger winds enhanced the surge by a more significant amount at Heysham (Table 2) compared with Hilbre (Table 3), while sea level rise has less impact at Heysham compared with Hilbre. For this area Lowe et al. (2001) also concluded that sea level rise would have more significant impact on the peak surge than changes in meteorological forcing.

\begin{tabular}{|l|l|l|l|}
\hline & \multicolumn{4}{l|}{ Increase in $\boldsymbol{U}_{\mathbf{1 0}}$} \\
\hline Sea level rise & $\mathbf{0 \%}$ & $\mathbf{5 \%}$ & $\mathbf{1 0} \%$ \\
\hline $\mathbf{0 m}$ & - & 1.92 & 4.01 \\
\hline $\mathbf{0 . 7 m}$ & 4.29 & 6.26 & 8.40 \\
\hline $\mathbf{1 . 4 m}$ & 9.295 & 11.27 & 13.41 \\
\hline
\end{tabular}

Table 1 Percentage change in peak surge elevation at Douglas. The 1977 peak surge reached $0.668 \mathrm{~m}$

\begin{tabular}{|l|l|l|l|}
\hline & \multicolumn{3}{l|}{ Increase in $\boldsymbol{U}_{\mathbf{1 0}}$} \\
\hline Sea level rise & $\mathbf{0 \%}$ & $\mathbf{5 \%}$ & $\mathbf{1 0} \%$ \\
\hline $\mathbf{0 m}$ & - & 6.83 & 13.99 \\
\hline $\mathbf{0 . 7 m}$ & 12.13 & 18.41 & 24.99 \\
\hline $\mathbf{1 . 4 m}$ & 22.73 & 28.43 & 34.42 \\
\hline
\end{tabular}

Table 2 Percentage change in peak surge elevation at Heysham. The 1977 peak surge reached $1.673 \mathrm{~m}$

\begin{tabular}{|l|l|l|l|}
\hline & \multicolumn{3}{|l|}{ Increase in $\boldsymbol{U}_{\mathbf{1 0}}$} \\
\hline Sea level rise & $\mathbf{0 \%}$ & $\mathbf{5 \%}$ & $\mathbf{1 0 \%}$ \\
\hline $\mathbf{0 m}$ & - & 5.99 & 12.38 \\
\hline $\mathbf{0 . 7 m}$ & 14.73 & 20.35 & 26.36 \\
\hline $\mathbf{1 . 4 m}$ & 27.23 & 32.54 & 38.19 \\
\hline
\end{tabular}

Table 3 Percentage change in peak surge elevation at Hilbre. The 1977 peak surge reached $1.242 \mathrm{~m}$

Fig. 7 shows how increased sea level modifies the surge. At both the shallow (Hilbre and Heysham) and deep (Douglas) locations the amplitude of the surge peaks is increased, due to higher peak surge elevations and lower minimum surge elevation. This can be attributed to changes in the tide and bottom friction affecting the tide-surge interaction, which controls the modulation of the surge. The total water level at high water determines the extent of coastal flooding. At high water levels the surge may be reduced due to increased sea level (lower minimum surge elevations in Fig. 7), but the increase in total water levels due to sea level rise will still pose more frequent flood risk (Lowe et al, 2001). Surprisingly there is also a phase shift in the surge at Douglas, the deeper location, such that it occurs later. The timing of the peak in total water level is consistent for varying sea levels at this location. The lag in surge peak is thought to be related to modified tide-surge interaction as a result of sea level rise also modifying the tides at this location. 

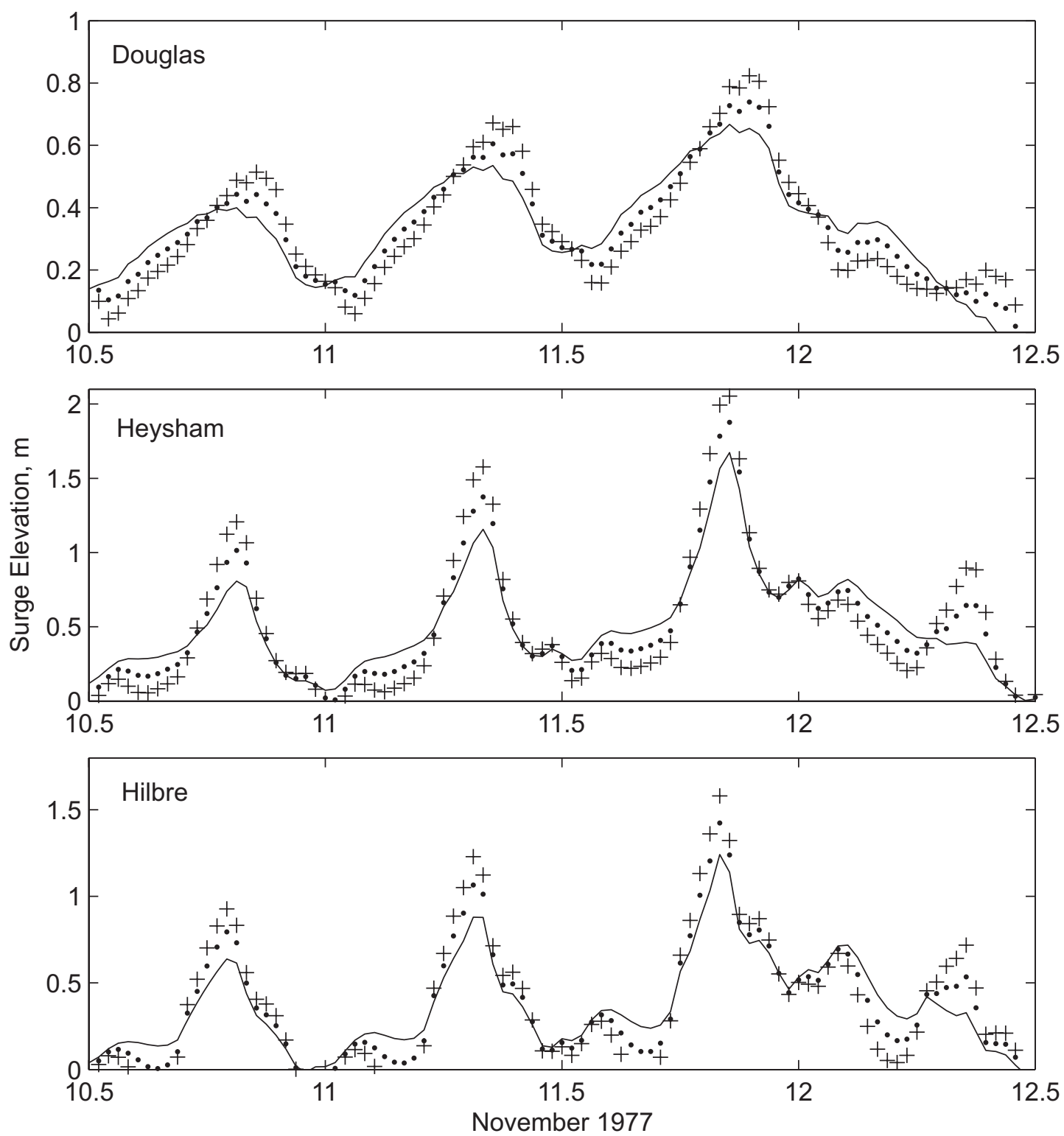

Fig. 7 The surge prediction at Douglas, Heysham and Hilbre for present day conditions (-) and with sea level rises of $0.7 \mathrm{~m}(\bullet)$ and $1.4 \mathrm{~m}(+)$. The time resolution is the day in November, e.g. 10 $=00: 0010^{\text {th }}$ November and 10.5 $=12: 0010^{\text {th }}$ November

Fig. 8 shows how increase wind speed increases the peak surge at shallow (Heysham and Hilbre) and deep (Douglas) locations. The increased wind causes the surge to achieve higher elevations throughout the event, i.e. the curve is shifted to higher elevations in Fig. 8. This shift is greater the larger the surge elevation, i.e. the peaks in surge during low water levels undergo greater enhancement. 

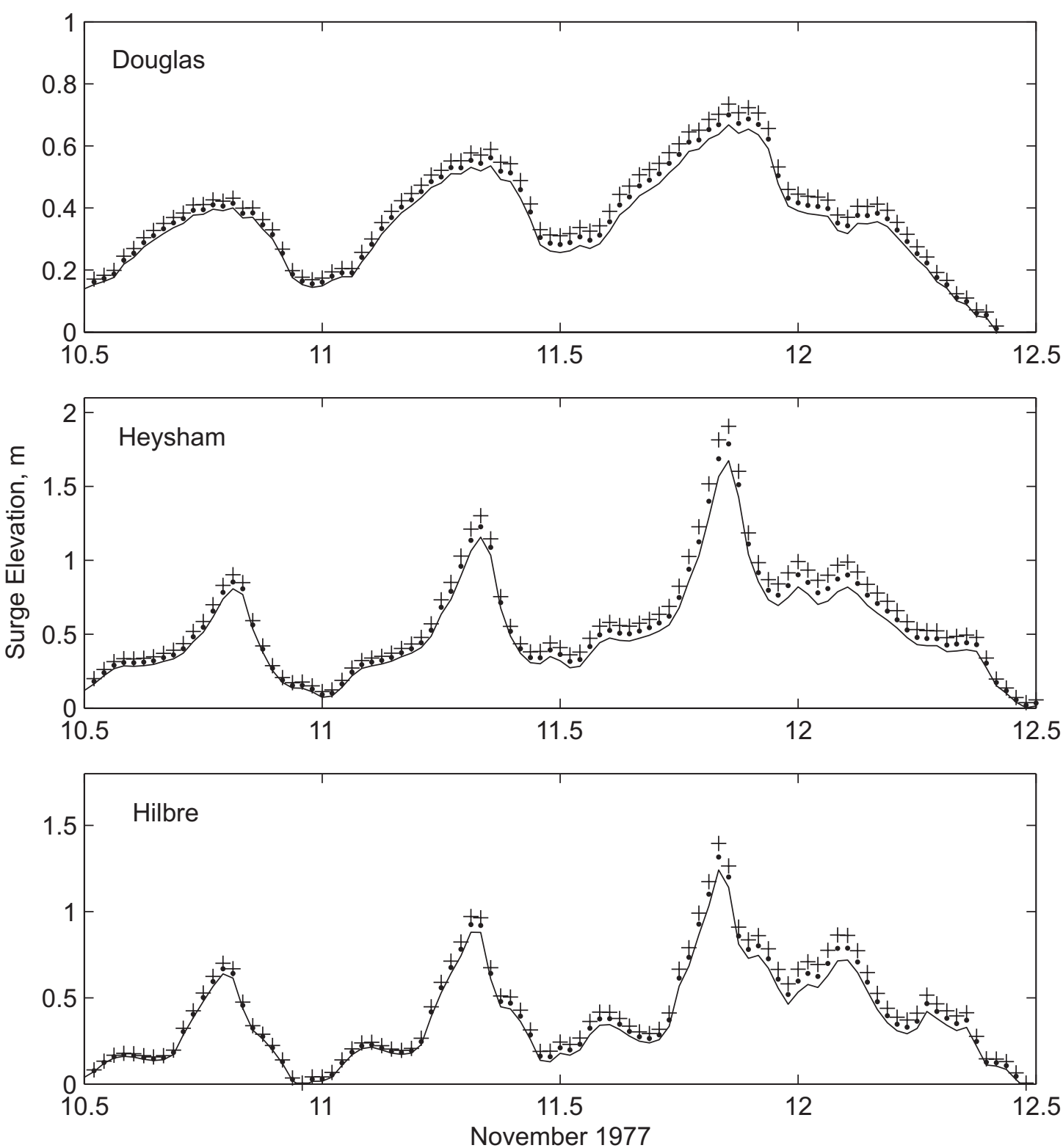

Fig. 8 The surge prediction at Douglas, Heysham and Hilbre for present day conditions $(-)$ and with enhanced wind speeds of $5 \%(\bullet)$ and $10 \%(+)$. The time resolution is the day in November, e.g. $10=$ 00:00 $10^{\text {th }}$ November and 10.5 $=12: 0010^{\text {th }}$ November

Fig. 9 shows how the most extreme increase in sea level $(+1.4 \mathrm{~m})$ and wind speed $(+10 \%)$ affects the surge. Again there is a phase shift at Douglas, the deeper location, such that the surge occurs later when sea levels are increased. At all locations the increased water depth increases the peak surge and reduces the minimum surge levels. Enhanced winds combined with sea level rise increases the surge height throughout the simulation compared to that in which only the sea levels are increased. This shift is greater for the peaks in surge and is most significant at Hilbre, the shallowest estuarine location. 

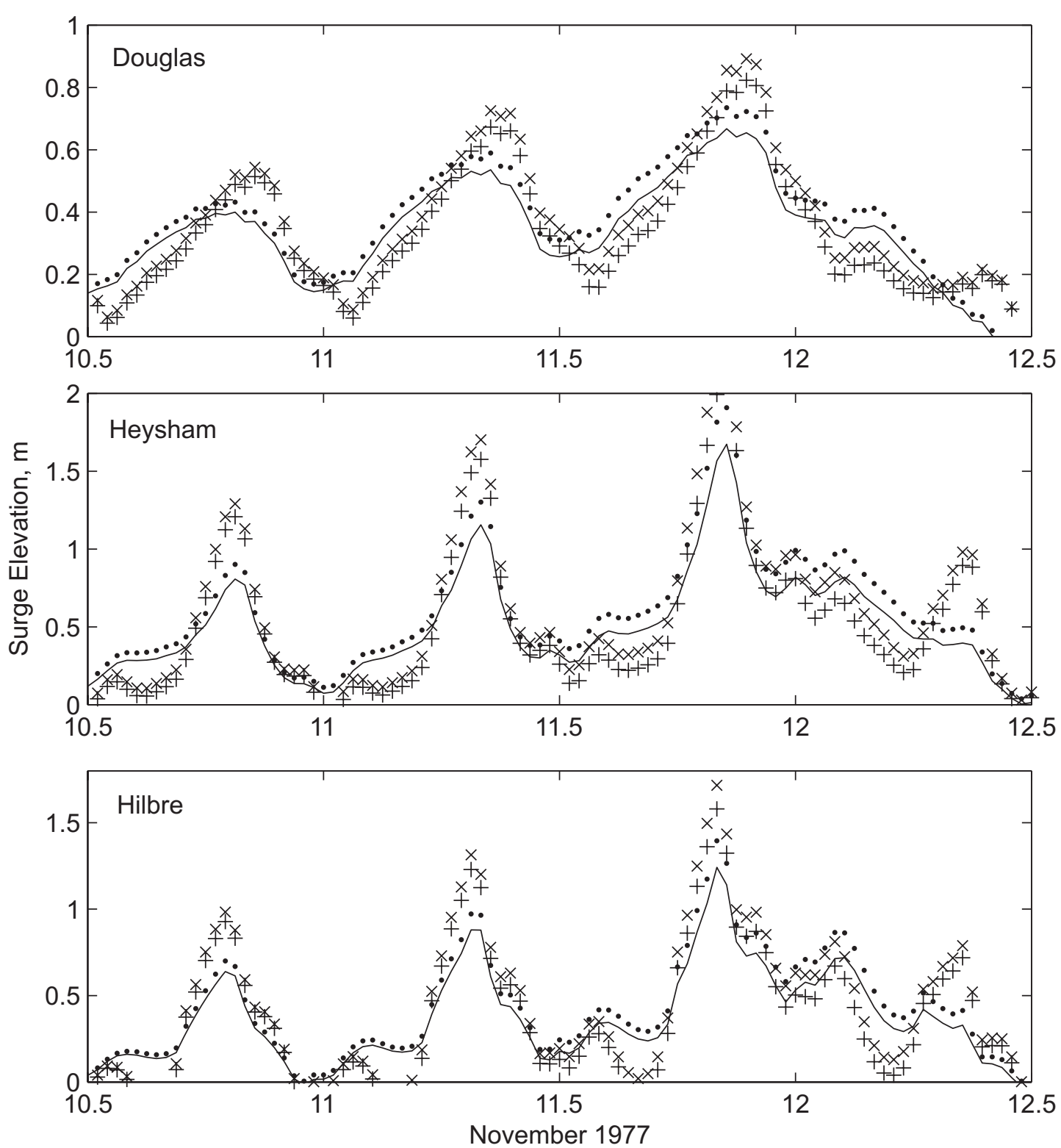

Fig. 9 The surge prediction at Hilbre and Douglas for present day conditions $(-)$, present day conditions with enhanced wind speeds of $10 \%(\bullet)$ and $1.4 \mathrm{~m}$ sea level rise $(+)$, and combined $1.4 \mathrm{~m}$ sea level rise and $10 \%$ wind enhancement $(\times)$. The time resolution is the day in November, e.g. $10=00: 0010^{\text {th }}$ November and 10.5 $=12: 0010^{\text {th }}$ November

5.2 Future residual flow patterns

We now look at the effect of the surge on the residual depth-averaged velocities at the same three locations as in section 5.1. We initially analyse the effects of future conditions at Douglas, the deeper coastal location. Figure 10 shows that the trend in magnitude (length) of the residual surge current vectors through time has three distinct peaks, like the residual surge elevation. At this deep location the residual flow is generally in a northwest direction, i.e. in the flood tide direction. Since the wind direction is south westerly until mid-day on the $11^{\text {th }}$ November when it veers west, the residual surge is driven by the winds across the Irish Sea. The residual magnitude is modulated by the tide, causing weaker velocities to occur at times of high water (Fig. 4) and greater velocities at low water. Although the magnitude of the residual increases with wind velocity the direction remains constant in the direction of the wind during the initial stages of the surge. This demonstrates that the duration of the wind in a particular direction is important at this location, veering in the wind takes time to impact the residual surge currents. For this location an increase in the wind velocity by $10 \%$ (bottom panel, Fig. 10) had greater impact on the magnitude of the residual velocity than increasing the present day sea level by $1.4 \mathrm{~m}$ (top panel, Fig. 10). 

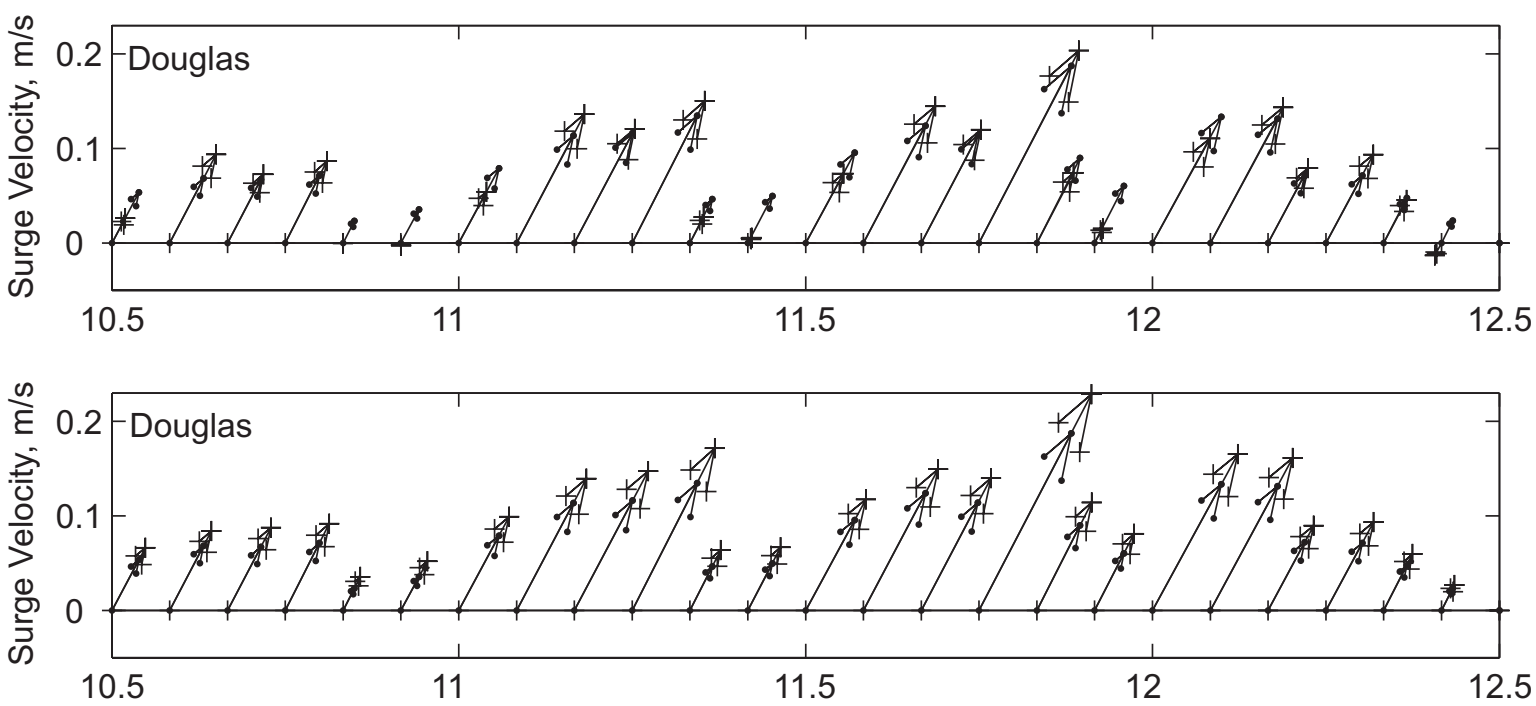

November 1977

Fig. 10 Surge (residual) depth - averaged current vectors every 2 hours at Douglas, located in Fig. 3, during the period $10^{\text {th }}$ November $(12: 00)$ to $12^{\text {th }}$ November $(12: 00) 1977$. The vector arrows depicted with dotted end points represent the actual 1977 surge conditions, while the arrows depicted by crossed end points represent the 1977 surge under future scenario conditions as follows: In the top panel a $1.4 \mathrm{~m}$ sea level rise is included and in the bottom panel a 10\% increase in wind speed is included. The time resolution is the day in November, e.g. $10=00: 0010^{\text {th }}$ November and 10.5 $=12: 0010^{\text {th }}$ November

At Heysham (Fig. 11), a shallow location at the northern end of the Sefton coast, the residual surge velocity is often in the counter direction to the tidal flow and not determined by the wind direction as at Douglas (Fig. 10). The largest residuals occur around high water (Fig. 4) as the tide turns. Similarly to Hilbre (Fig. 12), the effect of a $1.4 \mathrm{~m}$ sea level rise has more impact (top panel, Fig. 12) on the enhancement of the residual velocities than a 10\% increase in the wind velocity (bottom panel, Fig. 11). The increase in sea level also causes a slight change in the direction of the residual current at certain times of the tide.
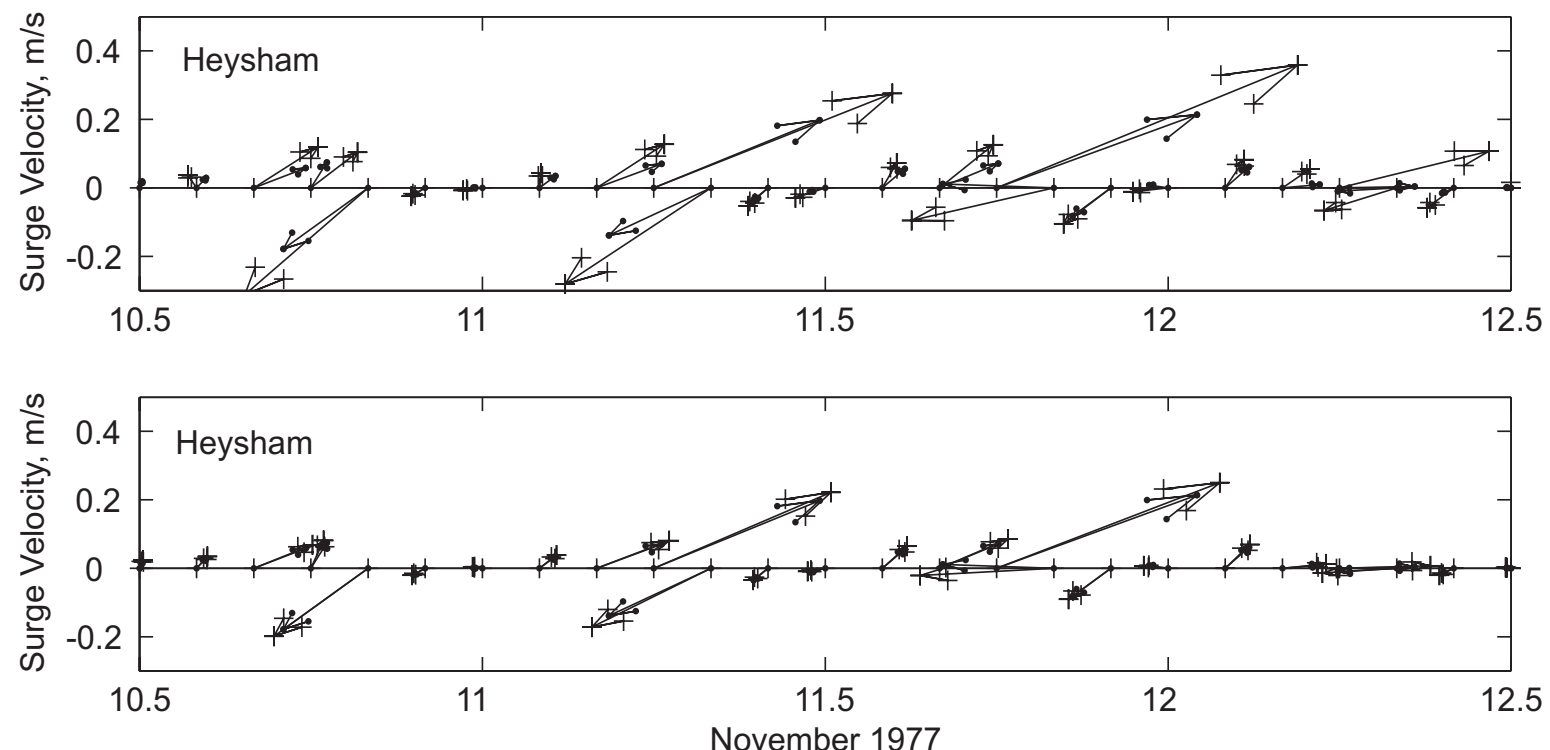

Fig. 11 Surge (residual) depth - averaged current vectors every 2 hours at Heysham, located in Fig. 3, during the period $10^{\text {th }}$ November $(12: 00)$ to $12^{\text {th }}$ November $(12: 00) 1977$. The vector arrows depicted with dotted end points represent the actual 1977 surge conditions, while the arrows depicted by crossed end points represent the 1977 surge under future scenario conditions as follows: In the top panel a $1.4 \mathrm{~m}$ sea level rise is included and in the bottom panel a 10\% increase in wind speed is included. The time resolution is the day in November, e.g. $10=00: 0010^{\text {th }}$ November and 10.5 $=12: 0010^{\text {th }}$ November 
The results for Hilbre (Fig. 12) are somewhat different to both other locations. At this shallow location in the mouth of the Dee Estuary, the residual surge velocity is generally out of the estuary (in a positive direction). The residual flow pattern does not follow the same trends as the surge. Contrary to the results for Douglas (Fig. 10), the largest residual occurs close to high water (Fig. 4) and is a factor of 2 greater than the peak residual velocity at Douglas. For Hilbre this is also the time for peak flood flow. For all other states of the tide the residual is weaker than at Douglas and Heysham. Again the effect of a $1.4 \mathrm{~m}$ sea level rise (top panel, Fig. 12) leads to greater enhancement of the residual velocities and also causes a slight change in the direction of the residual current at certain times of the tide. The $10 \%$ increase in the wind velocity (bottom panel, Fig. 12) has less effect than the change in sea level.
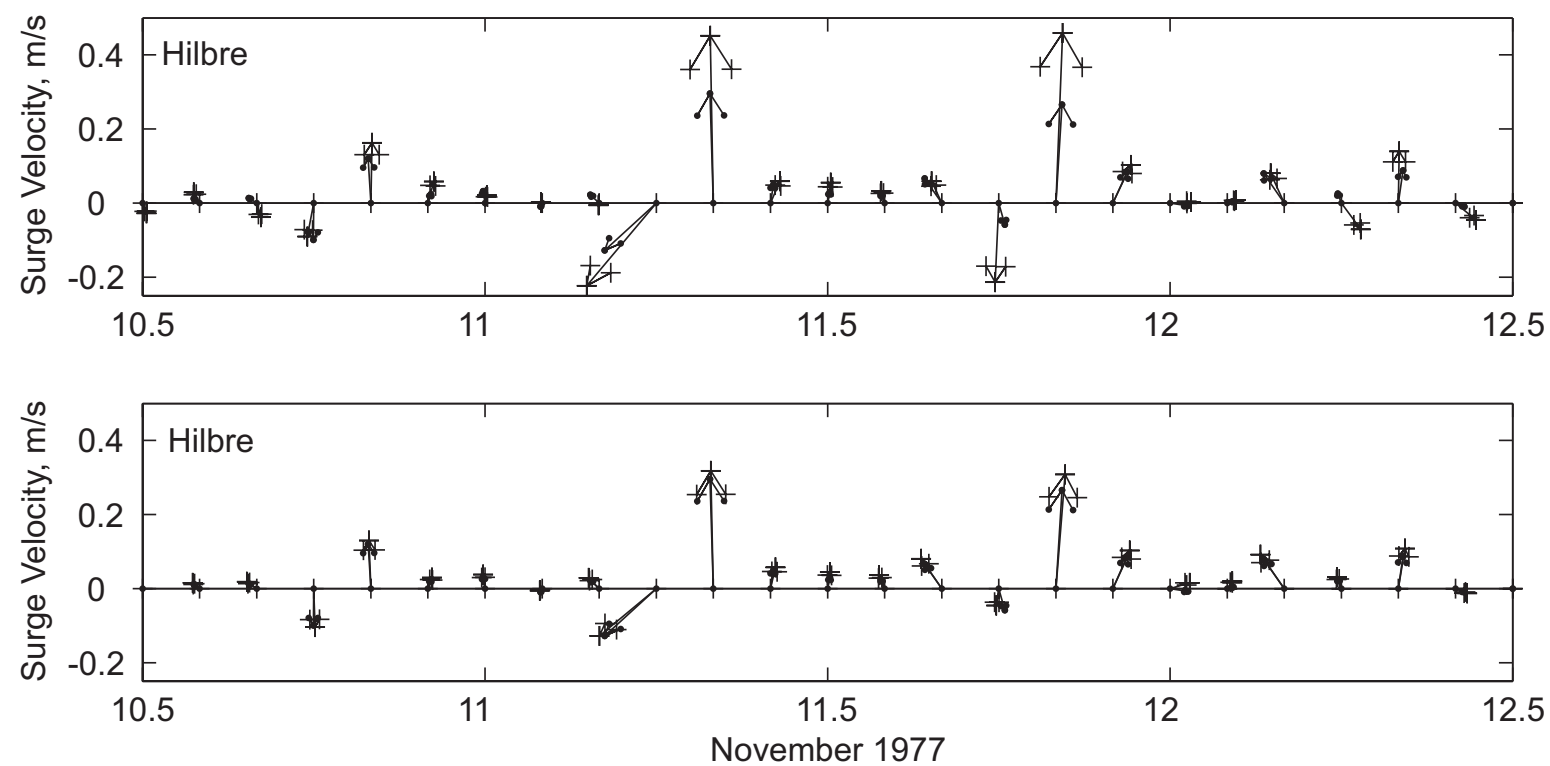

Fig. 12 Surge (residual) depth - averaged current vectors every 2 hours at Hilbre, located in Fig. 3, during the period $10^{\text {th }}$ November $(12: 00)$ to $12^{\text {th }}$ November (12:00) 1977 . The vector arrows depicted with dotted end points represent the actual 1977 surge conditions, while the arrows depicted by crossed end points represent the 1977 surge under future scenario conditions as follows: In the top panel a $1.4 \mathrm{~m}$ sea level rise is included and in the bottom panel a $10 \%$ increase in wind speed is included. The time resolution is the day in November, e.g. $10=00: 0010^{\text {th }}$ November and 10.5 $=12: 0010^{\text {th }}$ November

\section{Discussion}

A good tide-surge simulation in the Irish Sea results from using a constant Charnock parameter of 0.0185 . Interestingly the POL operational surge model, with $\sim 12 \mathrm{~km}$ resolution, requires a larger value of 0.0275 . We also notice that the S\&B prediction is quite valid in the Irish Sea $(\sim 1.8 \mathrm{~km})$ model, although it under-predicts when applied in the POL operational model. It is thought that the model resolution plays an important role in the optimum value for the Charnock parameter and the validity of the S\&B procedures. As the model grid becomes more highly resolved the average depth within each coastal grid cell is more accurately resolved. In low resolution models the average depth of the large grid cells may be greater in coastal zones compared with high resolution models. This greatly influences the effect of the surface stress on the water column. For low model resolution the stress must therefore be enhanced for accurate surge prediction at the coast. This enhancement is reduced with improved grid resolution and the S\&B method becomes more accurate.

Interestingly the residual surge velocity at Douglas occurs in the direction of the wind with longest duration across the Irish Sea. At Hilbre the residual is often in the direction of the northerly wind component, but can be into the estuary as the tide turns from ebb to flood. This could be the result of the enhanced water levels during the rising tide (Fig. 4) changing the tidal forcing at the estuary mouth. Although open-ocean Ekman dynamics should lead to a residual flow at $90^{\circ}$ to the right of the wind direction (Gill, 1982), this is not observed in the eastern Irish Sea. The residuals seem to generally be in the wind direction, due to the strong tidal currents and shallow $(<50 \mathrm{~m})$ depths in the eastern Irish Sea. For the peak wind velocity of $22 \mathrm{~m} / \mathrm{s}$ the Ekman depth is estimated to be $186 \mathrm{~m}$. The strong tidal currents also create a large vertical eddy viscosity profile and turbulent mixing preventing the formation of Ekman currents. Time varying winds (in strength and direction) during a real surge event also prevent a residual depth-averaged Ekman current pattern forming in the period of the surge. This is why significant surges are generated by winds over greatest fetch towards the eastern Irish Sea rather than alongshore winds in the eastern Irish Sea. 
The effect of waves on the surge events has also been investigated (Brown and Wolf, 2009). They find that the inclusion of a wave-dependent Charnock parameter has minimal difference compared with that using a constant value of 0.0185. An 11year simulation (1996 to 2007) following this model validation and that of Brown and Wolf (2009) is now underway to allow us to now investigate what storm conditions (wind and wave directions and strengths) pose the most significant threat to the Sefton coastline. This will enable a range of storm conditions to be tested under future scenario conditions and will provide a complete study of past, present and future extreme events for the Sefton coast.

We have found that for the 1977 storm conditions increased sea level has more impact on the increase in peak surge elevation than increased wind speeds. This result was also found by McInnes et al. (2009). The combined effect of these two changes can lead to a $20 \%$ to $40 \%$ increase in the peak surge relative to the present-day surge conditions on the coastal areas around Wirral, Merseyside and Sefton. The surge elevation along Sefton coast increases with distance to the north by about half a meter. Compared with Douglas (a deep location on the Isle of Man) the surge is much greater (nearly $1 \mathrm{~m}$ ) at shallow location along the Wirral, Merseyside and Sefton, coastline. When planning defences the total (tide + surge) water level is of most interest. Table 4 shows the percentage change in the peak of the total water level during the surge, which should be taken into account by managers. At Douglas the rise in sea level has more impact than the increase in wind speed, but the opposite is true for Heysham and Hilbre. Sea level rise has most impact on the surge peaks (during low water levels) (Fig. 7), while the winds influence the surge throughout the investigated time period (Fig. 8). Changes in the wind seem to have greater affect at the shallower locations (Table 4). At all locations the combined change is approximately the same as the linear addition of the percentage changes due to sea level and enhanced wind speeds. Although the surge at Hilbre is significantly large, the consequent flooding due to the total water level does not pose extreme risk to the coastal population, since there is an extensive volume of salt marsh, which will be flooded within the estuary before nearby towns become at risk. The size of the surge at high water along the Sefton coastline does pose a risk to the coastal population, as many towns are located on low lying land, e.g. Southport is built on reclaimed land. Along this coast the defences are in the form of naturally developed sand dune, which under future climate may become eroded by both the sea and wind. Not only does the increased surge elevation allow the dunes to be eroded and breached but the enhanced currents under future climate conditions will also scour the base of the dune system and alter the beach profile.

\begin{tabular}{|l|c|c|c|}
\hline Future Change & Douglas & Heysham & Hilbre \\
\hline$+\mathbf{1 0} \%$ wind increase & $1.35 \%$ & $2.55 \%$ & $2.20 \%$ \\
\hline$+\mathbf{1 . 4 m}$ sea level rise & $1.88 \%$ & $0.45 \%$ & $1.48 \%$ \\
\hline Both the above & $3.20 \%$ & $3.04 \%$ & $3.53 \%$ \\
\hline
\end{tabular}

Table 4 Percentage change in peak total water elevation at the study locations. The observed peak total water level at Douglas, Heysham and Hilbre were: $4.08 \mathrm{~m}, 5.49 \mathrm{~m}$ and $5.13 \mathrm{~m}$ respectively

\section{Conclusions}

The November 1977 storm surge events has previously been used to tune and validate the POLCOMS model surge predictions in the eastern Irish Sea, using this nested modelling system. We have shown that although the Smith and Banke formula under-predicts the peak surge, the Charnock method can be tuned to accurately predict a surge event at a given location. We find that the optimum Charnock value $(0.0185)$ is lower than that found by Williams and Flather (2000) (0.0275). This may be due to the higher model resolution that is applied here to the Irish Sea.

Future scenarios in the eastern Irish Sea have shown sea level rise combined with stronger winds will both significantly enhance the peak surge, perhaps, up to $40 \%$. This enhancement is greatest in shallow locations along the Sefton coastline, e.g. Hilbre and Heysham. We have shown that sea level rise has more impact than changing wind strength on the surge elevation, and thus greater potential for flood risk. Even if the wind speeds do not change significantly in the future a $0.7 \mathrm{~m}$ increase in sea level, which is likely to occur in the next 100 years, will enhance the surge elevation by up to $15 \%$. We can be certain that extreme storm conditions of today that cause large surge events along the Sefton coastline will have enhanced surge peaks in the future as further sea level rise is now inevitable (although the magnitude is uncertain e.g. IPCC, 2007). Defences along the Sefton coastline will therefore have to be carefully planned for future conditions involving storms combined with sea level rise.

For study, at Douglas the wind speed and duration has most influence on the surge velocities. The residual surge direction is controlled by the wind direction, while the strength is modulated by the tide. Future increases in wind velocity will have more potential to increase the current strength at Douglas than increase 
sea level. At Heysham the residual surge velocity varies in direction due to interaction with the tide and coastline. We find that for this location sea level has greater effect on the increase in the surge currents than increased wind speeds. At Hilbre the residual surge is generally out of the estuary due to the wind, increased sea levels rather than enhanced wind velocities pose greater risk with regard to faster surge currents.

From this study we can conclude that future changes in wind strength and sea level will lead to increased surge elevations and velocities. The enhancement of the peak velocity and elevation residuals will be greatest at shallow coastal locations. This will pose a threat to the sand dunes along the Sefton coast that act as a natural defence against surge events.

\section{Acknowledgments}

This research is part of the NERC FREE CoFEE (grant NE/E002471/1) and the EU FP7 MICORE (grant 202798) projects. Eric Jones is acknowledged for his help in providing wind and surge data for the 1977 event. ECMWF are also acknowledged for the use of their wind data to drive the course models.

\section{References}

Brown JM, Wolf J (2009) Coupled wave and surge modelling for the eastern Irish Sea and implications for model wind-stress. Accepted in Continental Shelf Research, doi: 10.1016/j.cr.2009.03.004

Charnock H (1955) Wind stress on a water surface. Quarterly Journal of the Royal Meterological Society, 81(350):639- 640

Gill AE (1982) Atmosphere-Ocean Dynamics. Academic Press, 662pp.

Holt JT, James DJ (2001) An s coordinate density evolving model of the northwest European continental shelf: 1, Model description and density structure. Journal of Geophysical Research, 106(C7): $14,015-14,034$

Horsburgh KJ, Wilson C (2007) Tide-surge interaction and its role in the distribution of surge residuals in the North Sea. Journal of Geophysical Research, 112, C08003, doi:10.1029/2006JC004033.

IPCC (2007) IPCC Fourth Assessment Report, Climate Change 2007 Synthesis Report. Pachauri, R.K. and Reisinger, A. (Eds.), Cambridge University Press, UK. IPCC, Geneva, Switzerland, 104pp.

Janssen PAEM (2004) The Interaction of ocean waves and wind. Cambridge University press, Cambridge, $300 \mathrm{pp}$

Janssen PAEM (1989) Wave-induced stress and the drag of air flow over sea waves. Journal of Physical Oceanography, 19(6):745 - 754

Jones JE, Davies AM (1998) Storm surge computations for the Irish Sea using a three-dimensional numerical model including wave-current interaction, Continental Shelf Research, 18(2): $201-251$

Komen GJ, Cavaleri L, Donelan M, Hasselmann K, Hasselmann S, Janssen PAEM (1994) Dynamics and modelling of ocean waves. Cambridge University Press. 532pp

Lowe JA, Gregory JM, Flather RA (2001) Changes in the occurrence of storm surges around the United Kingdom under a future climate scenario using a dynamic storm surge model driven by Hadley Centre climate models. Climate dynamics, 18(3-4): 179-188

Mastenbroek C, Burgers G, Janssen PAEM (1993) The dynamical coupling of a wave model and a storm surge model through the atmospheric boundary layer. Journal of Physical Oceanography, 23(8): $1856-1866$

McInnes KL, Macadam I, Hubbert GD, O’Grady JG (2009) A modelling approach for estimating the frequency of sea level extremes and the impact of climate Change in Southeast Australia. Natural Hazards, 51(1): 115 - 137

Monbaliu J, Padilla-Hernández R, Hargreaves JC, Carretero-Albiach JC, Luo W, Sclavo M, Günther H (2000) The spectral wave model WAM adapted for applications with high spatial resolution. Coastal Engineering, 41(1-3): $41-62$

Osuna P, Wolf J (2005) A numerical study on the effect of wave-current interaction processes in the hydrodynamics of the Irish Sea. In Proceedings of the 5th International Conference on Ocean Wave Measurement and Analysis: WAVES2005, 3rd to 7th July, 2005, Madrid, Spain, 10pp

Smith SD, Banke EG (1975) Variation of the surface drag coefficient with wind speed. Quarterly Journal of the Royal Meteorology Society, 101(429): 665 - 673

Taylor P., Yelland MJ (2001) The Dependence of Sea Surface Roughness on the Height and Steepness of the Waves. Journal of Physical Oceanography, 31(2):572 - 590

Williams JA, Flather RA (2000) Interfacing the Operational Storm Surge Model to a new Mesoscale Atmospheric Model. POL Internal Document, No. 127, Proudman Oceanographic Laboratory, Liverpool, U.K., 20pp

Wolf J (1981) Surge-tide interaction in the North Sea and River Thames. pp.75 - 94 in, Floods due to high winds and tides, (ed.D.H.Peregrine). 
Wolf J, Wakelin SL, Holt JT (2002) A coupled model of waves and currents in the Irish Sea. Proceedings of the Twelfth (2002) International Offshore and Polar Engineering Conference, Kitakyushu, Japan, May 26-31, 2002. 3:108-114

Woodworth PL, Tsimplis MN, Flather RA, Shennan I (1999) A review of the trends observed in British Isles mean sea level data measured by tide gauges, Geophysical Journal International 136 (3):651-670

Wu J (1980) Wind-stress coefficients over sea surface near neutral conditions-a revisit. Journal of Physical Oceanography, 10(5): $727-740$

Wu J (1982) Wind-Stress Coefficients Over Sea Surface From Breeze to Hurricane, Journal Geophysical Research, 87(C12), $9704-9706$ 